\title{
Mental Lexicon, Working Memory and L2 (English) Vocabulary in Polish Students with and without Dyslexia
}

Marta ŁoCKIEWICZ ${ }^{\star 1}$ AND MARTYNA JASKULSKA ${ }^{2}$

$\approx$ The aim of our study was to examine the relationship between access to the mental lexicon, working memory and knowledge of English (L2) vocabulary. Analyses were undertaken amongst monolingual speakers of Polish (26 with dyslexia, 24 without) who studied English as a second language as part of their compulsory educational programme at school. We assumed that students with dyslexia would manifest deficits in access to the mental lexicon and verbal working memory, and would have a limited L2 vocabulary. We also assumed that better access to the mental lexicon facilitates knowledge of English (L2) vocabulary, and that this relationship is present in both the criterion and the control group. All of the students participated in both parts of the assessment, the group part (i.e., questionnaire, IQ test, two vocabulary tasks) and the individual part (i.e., psychological measures: verbal working memory, RAN, verbal fluency, and single word reading in L1 task). We found that students with dyslexia exhibited deficits in the speed of access to data from the mental lexicon. The predictive function of memory for vocabulary was more conspicuous in the control group; in the criterion group, the result might constitute a risk factor for L2 vocabulary acquisition in dyslexia, which may manifest with increased proficiency in word knowledge. Poor vocabulary knowledge renders the L2 learning experience difficult, as it impairs students' reading comprehension, writing and conversational skills.

Keywords: dyslexia, English as L2, vocabulary, mental lexicon, working memory

$1 \quad{ }^{\star}$ Corresponding Author. University of Gdansk, Social Sciences Department, Gdańsk, Poland; psymlo@univ.gda.pl

2 University of Gdansk, Gdańsk, Poland 


\section{Mentalni leksikon, delovni spomin in besedišče v tujem jeziku (J 2) (angleščina) poljskih učencev z disleksijo oz. brez nje}

Marta Łockiewicz ${ }^{\star}$ IN Martyna JASKUlska

$\sim$ Namen raziskave je bil preveriti povezave med dostopom do mentalnega leksikona, delovnega spomina in poznavanjem angleškega ( $\begin{aligned} & \text { 2) } \\ & \text { 2) }\end{aligned}$ besedišča. $\mathrm{V}$ raziskavo so bili vključeni enojezični govorci poljščine (26 $\mathrm{z}$ disleksijo in 24 brez disleksije), ki so se učili angleščino kot drugi jezik kot del obveznega izobraževalnega programa v šoli. Avtorji so predvidevali, da se bo pri učencih z disleksijo pojavil primanjkljaj pri dostopanju do mentalnega leksikona in besednega delovnega spomina ter da bodo imeli omejeno besedišče J 2. Prav tako so predvidevali, da boljše dostopanje do mentalnega leksikona omogoča lažjo uporabo znanja besedišča $\mathrm{J} 2$ (angleščine) in da je ta povezanost prisotna pri učenci z disleksijo in tistih brez nje.

Vsi učenci so sodelovali $\mathrm{v}$ obeh delih ocenjevanja; $\mathrm{v}$ skupinskem delu (npr. vprašalnik, IQ-test, dve nalogi s področja besedišča) in individualnem delu (npr. psihološke meritve: besedni delovni spomin, RAN, besedna tekočnost in naloga branja posameznih besed $\mathrm{v}$ domačem jezi$\mathrm{ku}(\mathrm{J} 1)$ ). Raziskava je pokazala, da se pri učencih z disleksijo kažejo primanjkljaji pri hitrosti dostopanja do podatkov v mentalnem leksikonu. Napovedna funkcija pomena spomina za besedišče je bila očitnejša $v$ skupini učencev brez disleksije; rezultati skupine učencev $\mathrm{z}$ disleksijo bi lahko kazali na to, da disleksija predstavlja dejavnik tveganja pri pridobivanju besedišča v $\mathrm{J}$ 2, kar se lahko manifestira $\mathrm{z}$ višjo usposobljenostjo na področju poznavanja besed. Slabo poznavanje besedišča oteži učenje $\mathrm{J} 2$, ker poslabša učenčevo bralno razumevanje ter pisne in konverzacijske spretnosti.

Ključne besede: disleksija, angleščina kot J 2, besedišče, mentalni leksikon, delovni spomin 


\section{Introduction}

According to the International Dyslexia Association (Lyon Reid, Shaywitz, \& Shaywitz, 2003) "dyslexia is characterized by difficulties with accurate and/or fluent word recognition and by poor spelling and decoding abilities. These difficulties typically result from a deficit in the phonological component of language that is often unexpected in relation to other cognitive abilities and the provision of effective classroom instruction" (p. 2). These problems are observed in the native language $(\mathrm{L} 1)$, which has been a topic of extensive research (Beaton, 2004; Nicolson \& Fawcett, 2008); however, many deficits characteristic of dyslexia can also affect the learning of foreign languages (Crombie, 1997, 2000; Krasowicz-Kupis, 2008).

Our research is based on a theory proposed by Sparks and Ganschow (1993), which suggests that students who have poor results in learning a foreign language (L2) may have linguistic difficulties in their native language (L1) that interfere with their ability to learn L2. The authors of the theory connect L1 and L2 learning, indicating phonological coding as the main problem.

The importance of vocabulary (Carroll, 1993; Ouellette, 2006) and memory (Borkowska, 2006; Krasowicz-Kupis, 1999; Mather \& Wendling, 2012) in reading comprehension is undeniable. The richer our vocabulary is, the more complex texts we are able to understand. How do we understand what words mean? According to Perfetti (2007), readers are able to determine the meaning of words due to the complex rules of semantics (meaning), phonology (sound), orthography (spelling), morphology (word build) and syntax (sentence build). All of these factors contribute to word meaning comprehension. According to Coltheart's (2006) dual-route theory of reading, readers apply either a lexical strategy (consulting the mental lexicon when dealing with familiar words) or a non-lexical strategy (decoding an unfamiliar letter sequence). This has been confirmed in studies using event-related fMRI (Fiebach, Friederici, Müller, \& von Cramon, 2002). Kurcz (2000) defines mental lexicon (or mental dictionary) as an organisation of morphemes that includes intuitive knowledge about semantic, syntactic, phonological and orthographic aspects of words in a given language. Quantitatively, it can be studied using words frequency. Verbal working memory deficits (M. Bogdanowicz, 2004a; Lundberg \& Hoien, 2001; Swanson \& Sáez, 2003) and long-term memory deficits (M. Bogdanowicz, 2004a; Lundberg \& Hoien, 2001) have been reported as characteristic of dyslexia.

Woźnicki and Zawadzka (1981) emphasise the importance of organising the process of teaching a foreign language taking into account the characteristics of both working memory (e.g., presentation of a limited amount of new 
material) and long-term memory (e.g., systematic rehearsals, automatisation). Students may choose from various techniques when learning new vocabulary: word lists, mind maps, flashcards, associations (e.g., creating ridiculous sentences), learning through touching (e.g., using word models made from different fabrics), reading (words in context), listening and speaking. Vocabulary teaching, on the other hand, is most effective when combining two strategies: presenting new words in context, e.g., in reading passages (incidental learning) with definitions, or through direct instruction (explicit learning) (Sonbul \& Schmitt, 2010; Stahl \& Fairbanks, 1986). As far as young learners are concerned, some researchers argue that vocabulary learning through context brings fewer gains than through direct instruction (Jenkins, Matlock, \& Slocum, 1989). A similar approach is presented by Kucan (2012), who argues that engaging students in instructional sequences that focus directly on word meaning is most promising in teaching new vocabulary. Teachers should decide which words to teach, and this choice should be based on the particular knowledge of the students, their backgrounds, interests and experiences. Lessons during which vocabulary items are taught should be very carefully planned, consisting of meaningful dictionary explanations, engaging activities that make use of the new vocabulary in various contexts, and assessment of the students' progress. Kucan (2012) also underlines the fact that working with new vocabulary should be done over time. Regular learning can support the students' performance. Linguists have noticed that the more people read, the more opportunities they have to encounter new words in context (Anderson, Wilson, \& Fielding, 1988). Regular practice in reading enables people not only to acquire new vocabulary, but also to consolidate their knowledge of vocabulary. This is especially true of skilled readers, who can infer more from the context than poor readers (Swanborn \& de Glopper, 2002). A lack of reading practice may therefore constitute an additional risk factor in learning L2 for students with dyslexia, who often have reduced reading experience (M. Bogdanowicz, 2004a; Lyon Reid et al., 2003).

The difficulty of a word for a learner may be assessed using word frequency, which is the number of times a word appears in a text corpus (Johns, Gruenenfelder, Pisoni, \& Jones, 2012). In terms of their frequency, words can be divided into three categories: high, mid and low frequency, where high-frequency words are those that we use most often (either in speaking or writing). The higher the frequency, the more exposed the speaker is to the word. According to Laufer (1997), high frequency words are easier to remember due to more frequent exposure to them. However, teachers observe that high-frequency words are hard for young learners to remember because they tend to be abstract 
and are difficult to illustrate, e.g., the or with (Chen). Learning to recognise high-frequency words by sight is critical to developing fluency in reading, as it gives the student a basic context for deciphering other words. However, Polish children aged 6-9 do not go through a logographic phase in reading (Krasowicz-Kupis, 1999; Sochacka, 2004), analogical to the phase observed in English children.

The aim of our study was to examine the relationship between access to the mental lexicon and knowledge of English (L2) vocabulary. Analyses were undertaken within two groups: Polish (L1) students with dyslexia, as compared with Polish students without dyslexia. The participants were monolingual speakers of Polish who studied English as a second language as part of their compulsory educational programme at school. We assumed that students with dyslexia would manifest deficits in access to the mental lexicon and working memory, and would have a limited L2 vocabulary. We also assumed that better access to the mental lexicon facilitates knowledge of English (L2) vocabulary, and that this relationship is present in both the criterion and the control group.

\section{Method}

\section{Participants}

$30(50 \%)$ junior high school students with dyslexia and 30 (50\%) without dyslexia, all of whom attended the same schools and were taught by the same English teachers, participated in our study. They were matched by gender, age $\left(M_{\text {age }}=14.5, S D_{\text {age }}=0.67\right.$, range: 13.17 to $\left.15.58 \mathrm{yrs}\right), \mathrm{IQ}, \mathrm{ADHD}$ (no student had an ADHD report), and years of studying English at school and privately (see Table 1). The participants were native speakers of Polish. All of the students and their parents consented to participate after having been informed about the aims of the study and its procedure. The students in the criterion group all had an independent report issued by state psychological and educational counselling centres, confirming the diagnosis of dyslexia. Moreover, their accuracy and speed of reading single actual words in L1 was poorer than that of the participants without dyslexia, with their speed of reading being more than 1SD below control group performance. Both of the groups had studied English for seven years, which reflects the general rule in Poland of taking a foreign language course (predominantly English) as early as in the $1^{\text {st }}$ year of primary school education (which corresponds to seven years of age in the case of our participants). A foreign language exam is an obligatory part of external written and/or spoken exams taken when graduating from particular academic levels in the Polish educational system (primary, junior high school, high school) 
(www.cke.pl). In addition, $62 \%$ of the students with dyslexia and $38 \%$ of those without dyslexia were taking extracurricular private tutoring $\left(\chi^{2}(1)=0.43\right.$, $\mathrm{p}=.570$ ), either with an individual tutor or at a language school. The students of both groups declared that they did not like to read $(M=2.69, S D=1.05$ for the criterion group, $M=2.71, S D=1.23$ for the control group, $t(93)=0.50, p=.965$; self-reported on a scale from 1 to 7 , where 1 meant $I$ definitely do not like reading, and 7 meant $I$ definitely like reading).

Table 1. Descriptive characteristics of the compared groups

\begin{tabular}{|c|c|c|c|c|c|}
\hline & \multicolumn{2}{|c|}{ students with dyslexia } & \multicolumn{2}{|c|}{$\begin{array}{l}\text { students without } \\
\text { dyslexia }\end{array}$} & \\
\hline & female & male & female & male & \\
\hline gender $^{b}$ & $12(20)$ & $18(30)$ & $18(30)$ & $12(20)$ & $\chi^{2}(1)=2.4, p=.121$ \\
\hline $\operatorname{age}^{\mathrm{a}}$ & $14.42(0.67)$ & & $14.42(0.58)$ & & $t(58)=0.10, p=.918$ \\
\hline$I^{a}$ & $48.37(5.01)$ & & $48.53(5.70)$ & & $t(58)=0.12, p=.905$ \\
\hline \multicolumn{6}{|c|}{ years of studying English ${ }^{\mathrm{b}}$} \\
\hline at school & $7.31(1.22)$ & \multicolumn{3}{|c|}{$6.86(1.83)$} & $t(48)=1.05, p=.299$ \\
\hline private tutoring & $4.91(3.15)$ & \multicolumn{3}{|c|}{$3.75(2.71)$} & $t(17)=0.84, p=.413$ \\
\hline \multicolumn{6}{|c|}{ single word reading in L1: accuracy ${ }^{a}$} \\
\hline $\begin{array}{l}\text { actual words read } \\
\text { correctly }\end{array}$ & $77.67(9.27)$ & \multicolumn{3}{|c|}{$83.9(5.74)$} & $\begin{array}{l}U=265.5, Z=3.17 \\
p=.002, r=0.41\end{array}$ \\
\hline \multicolumn{6}{|c|}{ single word reading in L1: fluency ${ }^{a}$} \\
\hline $\begin{array}{l}\text { time of reading ac- } \\
\text { tual words (in sec.) }\end{array}$ & $110.93(44.42)$ & \multicolumn{3}{|c|}{$73.50(14.85)$} & $\begin{array}{l}t(58)=4.38 \\
p \leq .001, d=1.15\end{array}$ \\
\hline
\end{tabular}

Note: ${ }^{\mathrm{a}}=$ mean figures given (SD in parenthesis), ${ }^{\mathrm{b}}=$ actual figures given (\% in parenthesis)

\section{Procedure}

The study reported in the present article was part of a larger research project investigating $\mathrm{L}_{1}$ and L2 learning difficulties of Polish students with dyslexia. The project was conducted in the Pomeranian region in northern Poland. All of the students participated in both parts of the assessment, the group part (i.e., questionnaire, IQ test, two vocabulary tasks) and the individual part (i.e., psychological measures: working memory, RAN, verbal fluency, and single word reading in L1 task).

\section{Materials}

Questionnaire - two short questionnaires developed by the authors for the study, in order to acquire the necessary demographic information about the 
students (e.g., age, gender, dyslexia report, ADHD report), and data related to the learning of languages (years of studying English at a state school and during private tutoring, written word exposure). These were completed by the participants and their parents.

Test Matrices. Standard version - (Raven, 1991). A Polish adaptation, in order to match the compared groups in terms of intelligence level.

Single real word reading task in Polish - by Krasowicz-Kupis (Jaworowska, Matczak, \& Stańczak, 2010). A list of unrelated, single, real Polish words to be read aloud, in order to assess decoding in L1. This task is commonly used in Poland as one of the measures when diagnosing dyslexia in state psychological and educational counselling centres. The maximum score is 89 . The number of words read correctly was recorded, and the time of reading was measured. Syllable blending and self-corrections were treated as mistakes, as per the test instructions. This measure was used to confirm that our criterion group exhibited reading and spelling difficulties.

Vocabulary tasks in English - by Nation (2001; 1990). The tasks assess the receptive knowledge of vocabulary. Two tasks of increasing difficulty were chosen, based on the reducing frequency of the items included: 1000 (maximum score $=39$ points) and 2000 (maximum score $=18$ points) most common words. This task was chosen because it is constructed as a multiple choice question (in part 1, questions are answered with yes, no, or I don't understand the question; in part 2, words are matched with their definitions), which eliminates the confounding factor of correct spelling skill, especially in the criterion group. A simple proportional transformation was used to compare the level of difficulty of these two tasks with different maximum scores. Each score from the Vocabulary 10oo-frequency task was multiplied by the proportion 18/37 (maximum score in Vocabulary 20oo-frequency / maximum score in Vocabulary 10oo-frequency) in order to scale it down to a scale with a maximum of 18 points.

Wechsler Memory Scale III - (Pąchalska \& Lipowska, 2006). A Polish adaptation. One subtest was selected: Digit Span (forward and backward), which assesses verbal working memory.

Rapid Automatised Naming Test - Bogdanowicz, Kalka, Karpińska, Sajewicz-Radtke, and Radtke (2012), task SN2a. This task measures visual-auditory integration, long-term verbal memory, rapid automatised naming and divisibility of attention, and is based on the double-deficit theory advocated by Wolf and Bowers (1999, 2000; Wolf, Bowers, \& Biddle, 2000). Participants name six familiar objects, presented as colourful pictures (e.g., a pin, a starfish, a binder). All of the original Polish words consist of 2-4 syllables. We counted the number 
of correct responses and measured the time of performance. Each mistake was added to the time score as one second, as per the task instructions. This task is commonly used in Poland as one of the measures when diagnosing dyslexia in state psychological and educational counselling centres.

Semantic verbal fluency task. This task evaluates long-term memory, concentration, attention, knowledge and linguistic functions. Within a time limit of one minute, the participants named as many animals as they could (using their L1 - Polish), which is a task commonly used in such procedures in Poland (Pąchalska, 2007). The total number of words listed by the participants was recorded, excluding neologisms, perseverations and repetitions.

\section{Results}

The relationship between working memory, long-term memory and L2 vocabulary in the compared groups

A t-test for independent samples demonstrated that students with dyslexia, as compared with students without dyslexia, scored lower in access to data from the mental lexicon, as measured with the speed of RAN performance (Table 2). However, their verbal working memory, as measured with Digits Span, was comparable to that of their normally reading peers. The two groups scored on a level in verbal fluency (as measured with the number of listed animals) and in both vocabulary tasks, although the students with dyslexia knew consistently fewer words in both tasks.

Table 2. L2 vocabulary, working memory and long-term memory in the compared groups - descriptive statistics

\begin{tabular}{|c|c|c|c|c|c|c|c|c|c|}
\hline & \multicolumn{4}{|c|}{ students with dyslexia } & \multicolumn{4}{|c|}{ students without dyslexia } & \\
\hline & M & SD & Min & $\operatorname{Max}$ & M & SD & Min & Max & \\
\hline \multicolumn{10}{|c|}{ vocabulary by frequency } \\
\hline 1000 & 22.63 & 6.47 & 9 & 34 & 24.80 & 6.68 & 11 & 37 & $\mathrm{t}(58)=1.28, \mathrm{p}=.207$ \\
\hline 2000 & 5 & 3.6 & 0 & 14 & 6 & 5.07 & 0 & 17 & $\mathrm{t}(58)=0.88, \mathrm{p}=.382$ \\
\hline \multicolumn{10}{|c|}{ working memory } \\
\hline forward & 7.33 & 1.24 & 5 & 10 & 7.77 & 1.63 & 5 & 12 & $t(58)=1.16, p=.252$ \\
\hline backward & 4.57 & 1.19 & 3 & 7 & 4.80 & 1.94 & 2 & 9 & $\mathrm{t}(58)=0.56, \mathrm{p}=.577$ \\
\hline \multicolumn{10}{|c|}{ long-term memory } \\
\hline $\begin{array}{l}\text { RAN - speed } \\
\text { (in sec.) }\end{array}$ & 42.70 & 10.97 & 23 & 67 & 34.17 & 7.17 & 25 & 53 & $\begin{array}{l}t(58)=3.53, p \leq .001 \\
d=0.93\end{array}$ \\
\hline verbal fluency & 20.30 & 5.03 & 10 & 32 & 22.1 & 5.72 & 13 & 33 & $t(58)=1.29, p=.200$ \\
\hline
\end{tabular}


In the dyslexia group, a t-test with dependent samples determined that the 1000-frequency vocabulary task was easier than the 200o-frequency task: $\mathrm{t}(29)=9.67, \mathrm{p} \leq 0.001)$. Similarly, in the control group, a t-test with dependent samples demonstrated that the vocabulary tasks differed significantly in their difficulty $\mathrm{t}(29)=6.92, \mathrm{p} \leq 0.001)$, with the 1000-frequency task being easier than the 2000-frequency task. No participant scored $100 \%$ of the points in any task. Furthermore, in the easiest task, the average scores in both groups were only slightly above half of the maximum possible points, and in the more difficult task they were well below this level.

In order to investigate the relationship between L2 vocabulary, working memory and long-term memory, we calculated Pearson Correlations (Table 3 \& Table 4).

In the control group, there were positive correlations between (Table 3):

- 1000 -frequency vocabulary, access to the mental lexicon (strong) and verbal working memory (backward) (moderate);

- 2000-frequency vocabulary and verbal working memory (backward) (strong);

- $\quad$ verbal fluency and access to the mental lexicon (strong).

- In the dyslexia group, there was a positive correlation between (Table 4):

- 200o-frequency vocabulary and access to the mental lexicon (moderate).

Table 3. L2 vocabulary, working memory and long-term memory - correlations in the control group

\begin{tabular}{llllll}
\hline & $\begin{array}{l}\text { 1000-frequency } \\
\text { vocabulary }\end{array}$ & $\begin{array}{l}\text { 2000-frequen- } \\
\text { cy vocabulary }\end{array}$ & $\begin{array}{l}\text { WM - } \\
\text { forward }\end{array}$ & $\begin{array}{l}\text { WM - } \\
\text { backward }\end{array}$ & $\begin{array}{l}\text { RAN- } \\
\text { speed }^{a}\end{array}$ \\
\hline WM - forward & n.s. & n.s. & & \\
WM - backward & $.415^{*}$ & $.531^{*}$ & $.366^{*}$ & & \\
RAN-speed & $-.663^{* *}$ & n.s. & n.s. & n.s. & \\
verbal fluency & n.s. & n.s. & n.s. & n.s. & $-.536^{* *}$ \\
\hline
\end{tabular}

${ }^{*} p \leq .05,{ }^{* *} p \leq .01$

Note: n.s. $=$ not significant

$\mathrm{a}=$ higher score signifies lower performance 
Table 4. L2 vocabulary, working memory and long-term memory - correlations in the dyslexia group

\begin{tabular}{llllll}
\hline & $\begin{array}{l}1000 \text {-frequency } \\
\text { vocabulary }\end{array}$ & $\begin{array}{l}2000 \text {-frequency } \\
\text { vocabulary }\end{array}$ & $\begin{array}{l}\text { WM - } \\
\text { forward }\end{array}$ & $\begin{array}{l}\text { WM - } \\
\text { backward }\end{array}$ & $\begin{array}{l}\text { RAN- } \\
\text { speed }\end{array}$ \\
\hline WM - forward & n.s. & n.s. & & & \\
WM - backward & n.s. & n.s. & n.s. & & \\
RAN-speed & n.s. & $-.476^{* *}$ & n.s. & n.s. & \\
verbal fluency & n.s. & n.s. & n.s. & n.s. & n.s. \\
\hline
\end{tabular}

${ }^{*} \mathrm{p} \leq .05,{ }^{* *} \mathrm{p} \leq .01$

Note: n.s. = not significant

${ }^{a}=$ higher score signifies lower performance

These findings were confirmed by a multiple regression, enter method, which demonstrated specific relationships between knowledge of vocabulary and verbal working memory (as measured with Digit Span Backward) and access to the mental lexicon (as measured with the speed of performance in the RAN task).

In the dyslexia group:

- $\quad$ working memory and access to the mental lexicon (entered as independent variables) predicted:

- 2000-frequency vocabulary (entered as a dependent variable), $F(2$, $27)=4.38, p=.022, R^{2}=.245, R_{\text {Adjusted }}^{2}=.189$, working memory accounted for $2 \%$ of variance, $B=.427, \beta=.142$, access to the mental lexicon accounted for $19 \%$ of variance, $B=-.061, \beta=-.441$.

In the control group:

- $\quad$ working memory and access to the mental lexicon (entered as independent variables) predicted:

- 1000-frequency vocabulary (entered as a dependent variable), $F(2$, 27) $=16.79, p \leq .001, R^{2}=.554, R_{\text {Adjusted }}^{2}=.521$; working memory accounted for $12 \%$ of variance, $B=1.174, \beta=.340$, access to the mental lexicon accounted for $38 \%$ of variance, $B=-.412, \beta=-.623$, and

- $\quad$ working memory (entered as an independent variable) predicted 2000 -frequency vocabulary (entered as a dependent variable), $F(1,28)=$ $10.98, p=.003, R^{2}=.282, R_{\text {Adjusted }}^{2}=.256, B=1.388, \beta=.531$ ), accounting for $28 \%$ of variance.

A multiple regression did not show a predictive function of either working or long-term memory for the 1000-frequency vocabulary task in the dyslexia group. 


\section{Discussion}

We found that students with dyslexia, as compared with students without dyslexia, exhibited deficits in the speed of the access of verbal data from the mental lexicon (as measured with the RAN task), which is consistent with literature reports (Krasowicz-Kupis, Borkowska, \& Pietras, 2009; Martin et al., 2010; Shessel \& Reiff, 1999; Szczerbiński, 2007; Wolf et al., 2000).

The two groups performed on a level in verbal working memory (as measured with Digit Span, forward and backward) and verbal fluency (as measured with listing animals within one minute), although the group with dyslexia scored lower in all three tasks as compared to the control group. The lack of differences in verbal fluency is consistent with the literature (Frith, Lander, \& Frith, 1995; Nicolson \& Fawcett, 1997), as we employed a semantic version of the task. However, a verbal working memory deficit is commonly listed amongst problems associated with dyslexia (Miles, 1993; Moura, Simões, \& Pereira, 2014; Szczerbiński, 2007), as this is a symptom characteristic of a phonological deficit, which is thought to be its cause (Beaton, 2004; Hoien, Lundberg, Stanovich, \& Bjaalid, 1995; Snowling, 2000). Although we did not find deficits in the group with dyslexia in this ability, we did observe a different pattern of relationship between verbal working memory and the knowledge of L2 vocabulary, which we discuss below. No differences between the groups (students with dyslexia vs. controls) in digits backward was also reported by Alves Ferreira de Carvalho, de Souza Batista Kida, Aparecida Capellini, and Brandão de Avila (2014), who attribute this result to the fact that this task measures a higher degree storage and the simultaneous processing of information rather than phonological skills. Couture and McCauley (200o) propose that recall problems in children with phonological impairment might be due to an interaction between shortterm memory and long-term memory phonological representations, rather than deficits in the phonological loop.

In our study, the students with and without dyslexia scored on a level in the $\mathrm{L} 2$ receptive language task, which does not confirm our assumptions. Polish studies of junior high school students have indicated a lower level of general linguistic competence, and of $\mathrm{L}_{1}$ receptive and active lexicon in participants with dyslexia, as compared to participants without dyslexia (Długosz \& Rejnowska-Wawryn, 2007). However, this research focused on vocabulary size in L1, in which students with dyslexia were fluent; the vocabulary of such students nonetheless proved to be limited in comparison with their normally reading peers. This diminished richness of known L1 words could be attributed to reduced reading experience, and has been indicated as such in definitions 
(Lyon Reid et al., 2003) or descriptions (M. Bogdanowicz, 2004a) of dyslexia. However, we do not think that reading experience in L2 could have had a substantial impact on the vocabularies of our participants, as both groups declared a general dislike for reading and exhibited limited L2 word knowledge. Similarly to L1 mental lexicon comparisons, smaller L2 (English) vocabulary size in dyslexia has been observed in Polish research (Jurek, 2004; Łockiewicz \& Jaskulska, in preparation); however, these studies have involved older, high school students, who were presumably more proficient in the language, having studied it on average for several years longer than our test group. We believe that the poor vocabulary knowledge of our participants (an apparent floor effect in the 2000-frequency task) contributed to the observed lack of differences between the two groups, differences that would become evident in more advanced L2 students.

Tomaszczyk claims that learning 2000 words is sufficient to communicate successfully in English. Lists of words differ depending on the material being analysed, but a list of English words exists that meets the requirements of language learners. Selected by a group of language experts and experienced teachers, this list contains words that should receive priority in L2 vocabulary acquisition due to their importance and usefulness. On the basis of our study, we can conclude that even the highest frequency words were problematic for our students. No participant, not even in the control group, scored $100 \%$ of the points in any vocabulary task. Moreover, in the 1000-frequency vocabulary task, both groups scored on average only slightly above half of the possible points, while in the more difficult 200o-frequency task the average result was approximately one third of the possible points. This suggests that, although the average period of learning English was seven years, the students' knowledge of vocabulary was very poor, as they struggled with even the easiest words, to which they had presumably often been exposed. As such a low score was obtained in a task based on recognition, which is an easier form of retrieval than recall, it is likely that producing words would yield even poorer scores. Moreover, we observed that the 1000-frequency vocabulary task was easier than the 20oo-frequency task for both groups. This result is in accordance with the finding that English-as-L2-language learners identify high-frequency English words faster and more accurately than low-frequency words (Wang \& Koda, 2007), and that L1 English high-frequency words are read faster by both children and adults (Joseph, Nation, \& Liversedge, 2013). Furthermore, learning a foreign language depends on both linguistic and non-linguistic factors, such as affective or cultural factors (Lundberg, 2002).

Our results confirm the role of verbal short-term and long-term 
memory in learning L2 vocabulary. In the control group, mental lexicon access and working memory (backward) predicted the knowledge of 1000-frequency vocabulary, while mental lexicon access alone accounted for $38 \%$ of variance. This result confirms the important role of memory in L2 vocabulary acquisition: phonological short-term memory (Baddeley, Gathercole, \& Papagno, 1998; Cheung, 1996; Gathercole, Service, Hitch, Adams, \& Martin, 1999; Masoura \& Gathercole, 2005) and long-term memory (Cheung, 1996; Masoura \& Gathercole, 2005). Only verbal working memory (backward) predicted 2000 -frequency vocabulary, accounting for $28 \%$ of variance. Research has shown that digits forward and digits backward are different constructs (Rosenthal, Riccio, Gsanger, \& Jarratt, 2006). Masoura and Gathercole (2005) claim that the participation of phonological short-term and long-term memory in L2 acquisition changes with the expansion of mental lexicon. Beginners rely mostly on temporary memory, while in advanced L2 learners word representations in mental lexicon mediate the learning of new words. Even though our students had studied English as L2 for a long time, their vocabulary knowledge could be assessed as that of a beginner, as they had only mastered the easiest set of words. Although they were able to employ their mental lexicon for familiar L2 1000-frequency words, in order to complete a more difficult L2 word task, which clearly included unfamiliar words, the students applied verbal short-term memory. Moreover, the lack of mental lexicon access predictive function in the 2000-frequency task may suggest that in order to perform this more challenging task the students relied on educated guesses more than on real word entries in their long-term memory.

In the dyslexia group, mental lexicon access and working memory predicted 2000- frequency vocabulary, but the former accounted only for $19 \%$ of variance, half as much as in the control group. Thomson, Richardson, and Goswami (2005) reported that children with dyslexia have impaired phonological representations of lexical items, which may impair or prevent the use of long-term phonological representations in short-term memory. Similarly, Elbro and Jensen (2005) found that students with dyslexia had less well-specified phonological representations of long, familiar L1 words than younger readingage matched controls. It may be that the students with dyslexia did not differentiate between familiar and unfamiliar words in the difficult task to the same extent as their peers without dyslexia. It is not clear why we did not observe a predictive function of either working or long-term memory for the 1000-frequency vocabulary task. This lack of relationship might be a result of deficits in verbal short-term and long-term memory in dyslexia. We therefore conclude that mental lexicon deficits might constitute a risk factor for L2 vocabulary 
acquisition in dyslexia, which may manifest with increased proficiency in word knowledge.

Moreover, in the control group, verbal fluency was linked to access to the mental lexicon, which confirms that these two tasks tap similar underlying abilities (cf. Pąchalska, 2007).

The students in both groups expressed a lack of interest in reading. However, we asked only a general question concerning reading preferences; it would be advisable to differentiate between reading in $\mathrm{L}_{1}$ and $\mathrm{L} 2$, as well as to include L2 exposure through other media, e.g., video games or films. Furthermore, the two groups did not differ in terms of working memory and L2 vocabulary. This lack of expected differences might be due to the small sample size, or to the fact that we did not screen our control group for other learning/achievement problems (e.g., sociocultural disadvantages, underachievement, etc.), except for ADHD. However, all of the students had achieved the same level of education and attended the same schools. Moreover, the control group scored higher in L1 language tasks than the criterion group. General poor results in vocabulary size in both the criterion and the control group calls for a modification of L2 instruction in elementary and junior high schools. Multisensory instruction has been proposed as an effective teaching method for children with dyslexia (K. Bogdanowicz, 2011; M. Bogdanowicz, 2004b), while an individualised approach is also required (K. Bogdanowicz, 2011). Such teaching techniques would also be beneficial for those students who do not have reading and writing difficulties. Furthermore, in our study, we concentrated on the receptive aspect of vocabulary, as we wanted to eliminate the possible confounding factor of spelling deficits in the criterion group. We recommend that future studies also include the productive aspect of vocabulary, as well as a comparison of L1 and L2 mental lexicon skills. It would also be interesting to examine the relationship between other aspects of L2 acquisition, such as accuracy and fluency of reading, spelling and phonological processing in $\mathrm{L}_{1}$ in normal readers and readers with dyslexia.

\section{Conclusions}

We found that students with dyslexia, as compared with students without dyslexia, exhibited deficits in the speed of access of data from the mental lexicon. No deficits in the criterion group were observed in verbal working memory (backward) and verbal fluency. However, the relationship between mental lexicon access, working memory (backward) and vocabulary was different in the two groups; the predictive function of memory for vocabulary was 
more conspicuous in the control group, especially in the case of knowledge of higher frequency words. This weaker relationship in the criterion group might constitute a risk factor for L2 vocabulary acquisition in dyslexia, which may manifest with an increased proficiency in word knowledge. Moreover, both students with and without dyslexia knew few L2 words, despite their long educational experience, and had failed to develop reading preferences. These findings suggest a need for L2 teachers to incorporate teaching techniques that would trigger students' interest in reading in L2, which might expand their exposure to L2 words. Poor vocabulary knowledge renders the L2 learning experience difficult, as it impairs students' reading comprehension, writing and conversational skills.

\section{Acknowledgements}

We would like to thank the students who participated in our study. Thanks are also due to Dorota Wieczorek and Renata Jażdżewska for their help in data collection, and to Professor Marta Bogdanowicz from the Institute of Psychology (University of Gdańsk) for organisational help and advice.

The authors were awarded a grant for the project from the University of Gdansk, registration number: 538-7416-B128-13, in 2013.

\section{References}

Alves Ferreira de Carvalho, C., de Souza Batista Kida, A., Aparecida Capellini, S., \& Brandão de Avila, C. R. (2014). Phonological working memory and reading in students with dyslexia. Frontiers in Psychology, 5, 1-10. doi: 10.3389/fpsyg.2014.00746

Anderson, R. C., Wilson, P. T., \& Fielding, L. G. (1988). Growth in reading and how children spend their time outside of school. Reading Research Quarterly, 13, 285-303.

Baddeley, A., Gathercole, S., \& Papagno, C. (1998). The phonological loop as a language learning device. Psychological Review, 105(1), 158.

Beaton, A. A. (2004). Dyslexia, Reading and the Brain. A Sourcebook of Psychological and Biological Research. Hove: Psychology Press, Taylor \& Francis Group.

Bogdanowicz, K. (2011). Dysleksja a nauczanie języków obcych. Przewodnik dla nauczycieli i rodziców uczniów z dysleksją. Gdańsk: Wydawnictwo Harmonia.

Bogdanowicz, M. (2004a). Co należy wiedzieć o dysleksji rozwojowej? Wprowadzenie teoretyczne. In M. Bogdanowicz \& A. Adryjanek (Eds.), Uczeń z dysleksją w szkole. Poradnik nie tylko dla polonistów (pp. 7-92). Gdynia: Wydawnictwo OPERON.

Bogdanowicz, M. (2004b). Niespecyficzne i specyficzne trudności w uczeniu się języków obcych. In M. Bogdanowicz \& M. Smoleń (Eds.), Dysleksja w kontekście nauczania języków obcych (pp. 78-97). 
Gdańsk: Wydawnictwo HARMONIA.

Bogdanowicz, M., Kalka, D., Karpińska, E., Sajewicz-Radtke, U., \& Radtke, B. M. (2012). Bateria metod diagnozy przyczyn niepowodzeń szkolnych u uczniów gimnazjów. Bateria GIM. Gdańsk: Pracownia Testów Psychologicznych i Pedagogicznych SEBG.

Borkowska, A. (2006). Neuropsychologiczne podłoże trudności w czytaniu i pisaniu. In G.

Krasowicz-Kupis (Ed.), Dysleksja rozwojowa. Perspektywa psychologiczna (pp. 35-51). Gdańsk:

Wydawnictwo HARMONIA.

Carroll, J. B. (1993). Human cognitive abilities: A survey of factor-analytic studies. New York, NY:

Cambridge University Press.

Chen, K. Retrieved 29 October 14 from http://www.eduplace.com/rdg/res/freguent.html

Cheung, H. (1996). Nonword span as a unique predictor of second-language vocabulary learning.

Developmental Psychology, 32(5), 867.

Coltheart, M. (2006). Dual Route and Connectionist Models of Reading: An Overview. London

Review of Education, 4(1), 5-17.

Couture, A. E., \& McCauley, R. J. (2000). Phonological working memory in children

with phonological impairment. Clinical Linguistics \& Phonetics, 14(7), 499-517. doi:

$10.1080 / 026992000750020332$

Crombie, M. A. (1997). The Effects of Specific Learning Difficulties (Dyslexia) on the Learning of a Foreign Language in School. Dyslexia, 3, 27-47.

Crombie, M. A. (2000). Dyslexia and the learning of a foreign language in school: where are we going? Dyslexia (Chichester, England), 6(2), 112-123. doi: 10.1002/(sici)1099-

0909(200004/06)6:2<112::aid-dys151>3.3.c0;2-4

Długosz, M., \& Rejnowska-Wawryn, B. (2007). Zastosowanie Testu Językowego Leksykon w diagnozie uczniów dyslektycznych. In M. Kostka-Szymańska \& G. Krasowicz-Kupis (Eds.), Dysleksja. Problem znany czy nieznany? (pp. 137-145). Lublin: Wydawnictwo Uniwersytetu Marii Curie-

Skłodowskiej.

Elbro, C., \& Jensen, M. N. (2005). Quality of phonological representations, verbal learning, and phoneme awareness in dyslexic and normal readers. Scandinavian Journal of Psychology, 46(4), $375-384$.

Fiebach, C. J., Friederici, A. D., Müller, K., \& von Cramon, D. Y. (2002). fMRI Evidence for Dual Routes to the Mental Lexicon in Visual Word Recognition. Journal of Cognitive Neuroscience, 14(1), 11-23. doi: 10.1162/089892902317205285

Frith, U., Lander, K., \& Frith, C. (1995). Dyslexia and Verbal Fluency: More Evidence for a Phonological Deficit. Dyslexia (10769242), 1(1), 2-11.

Gathercole, S. E., Service, E., Hitch, G. J., Adams, A.-M., \& Martin, A. J. (1999). Phonological shortterm memory and vocabulary development: further evidence on the nature of the relationship. Applied Cognitive Psychology, 13(1), 65-77.

Hoien, T., Lundberg, I., Stanovich, K. E., \& Bjaalid, I. K. (1995). Components of phonological awareness. Reading and Writing, $7(2), 171-188$. doi: 10.1007/bfo1027184 
Jaworowska, A., Matczak, A., \& Stańczak, J. (2010). Diagnoza dysleksji. Aneks do przewodnika diagnostycznego. Normalizacja dla uczniów klasy V szkoły podstawowej. Warszawa: Pracownia Testów Psychologicznych Polskiego Towarzystwa Psychologicznego.

Jenkins, J. R., Matlock, B., \& Slocum, T. A. (1989). Two approaches to vocabulary instruction: The teaching of individual word meanings and practice in deriving word meaning from context. Reading Research Quarterly, 24, 215-235.

Johns, B. T., Gruenenfelder, T. M., Pisoni, D. B., \& Jones, M. N. (2012). Effects of word frequency, contextual diversity, and semantic distinctiveness on spoken word recognition. Journal of the Acoustical Society of America, 132(2), EL74-EL8o. doi: 10.1121/1.4731641 Joseph, H. S. S. L., Nation, K., \& Liversedge, S. P. (2013). Using Eye Movements to Investigate Word Frequency Effects in Children's Sentence Reading. School Psychology Review, 42(2), 207-222. Jurek, A. (2004). Trudności w nauce języków obcych uczniów z dysleksją rozwojową. In M. Bogdanowicz \& M. Smoleń (Eds.), Dysleksja w kontekście nauczania języków obcych (pp. 98-116). Gdańsk: Wydawnictwo Harmonia.

Krasowicz-Kupis, G. (1999). Rozwój metajęzykowy a osiągnięcia w czytaniu u dzieci 6-9 letnich. Lublin: UMCS.

Krasowicz-Kupis, G. (2008). Psychologia dysleksji. Warszawa: Wyd. Nauk. PWN.

Krasowicz-Kupis, G., Borkowska, A. R., \& Pietras, I. (2009). Rapid automatized naming, phonology and dyslexia in Polish children. Medical Science Monitor, 15(9), CR460-CR469.

Kucan, L. (2012). What Is Most Important to Know About Vocabulary? Reading Teacher, 65(6), 360-366. doi: 10.1002/TRTR.01054

Kurcz, I. (200o). Psychologia języka i komunikacji. Warszawa: Wydawnictwo Naukowe SCHOLAR. Laufer, B. (1997). What's in a word that makes it hard or easy? Some intralexical factors that affect the learning of words. In N. Schmitt \& M. McCarthy (Eds.), Vocabulary: Description, Acquisition and Pedagogy (pp. 140-155). Cambridge: Cambridge University Press.

Lundberg, I. (2002). Second Language Learning and Reading with the Additional Load of Dyslexia. Annals of Dyslexia, 52, 165-187.

Lundberg, I., \& Hoien, T. (2001). Dyslexia and Phonology. In A. Fawcett (Ed.), Dyslexia. Theory and Good Practice (pp. 109-123). London: Whurr Publishers.

Lyon Reid, G., Shaywitz, S. E., \& Shaywitz, B. A. (2003). A Definition of Dyslexia. Defining Dyslexia, Comorbidity, Teachers' Knowledge of Language and Reading. Annals of Dyslexia, 53, 1-14.

Martin, J., Cole, P., Leuwers, C., Casalis, S., Zorman, M., \& Sprenger-Charolles, L. (2010). Reading in French-speaking adults with dyslexia. Annals of Dyslexia, 6o(2), 238-264. doi: 10.1007/s11881-0100043-8

Masoura, E. V., \& Gathercole, S. E. (2005). Contrasting contributions of phonological short-term memory and long-term knowledge to vocabulary learning in a foreign language. Memory, 13(3/4), 422-429. doi: 10.1080/09658210344000323

Mather, N., \& Wendling, B. J. (2012). Essentials of Dyslexia Assessment and Intervention. Hoboken, New Jersey: John Wiley \& Sons, Inc. 
Miles, T. R. (1993). Dyslexia - The Pattern of Difficulties. London: Whurr Publishers.

Moura, O., Simões, M. R., \& Pereira, M. (2014). WISC-III cognitive profiles in children with developmental dyslexia: specific cognitive disability and diagnostic utility. Dyslexia (Chichester, England), 20(1), 19-37. doi: 10.1002/dys.1468

Nation, P. (2001; 1990). Frequency based tests: Recognition. Retrieved 30 August 2014, from ?

Nicolson, R. I., \& Fawcett, A. J. (1997). Development of Objective Procedures for Screening and Assessment of Dyslexic Students in Higher Education. Journal of Research in Reading, 20(1), 77. Nicolson, R. I., \& Fawcett, A. J. (2008). Dyslexia, learning, and the brain. Cambridge, Mass. ; London: MIT.

Ouellette, G. P. (2006). What's Meaning Got to Do With It: The Role of Vocabulary in Word Reading and Reading Comprehension. Journal of Educational Psychology, 98(3), 554-566. doi: 10.1037/oo220663.98.3.554

Perfetti, C. (2007). Reading Ability: Lexical Quality to Comprehension. Scientific Studies of Reading, 11(4), 357-383. doi: 10.1080/10888430701530730

Pąchalska, M. (2007). Neuropsychologia kliniczna. Urazy mózgu. Warszawa: Wydawnictwo Naukowe PWN.

Pąchalska, M., \& Lipowska, M. (2006). Skala Pamięci Wechslera (WMS-III). Autoryzowana Wersja Polska. Kraków: Fundacja na Rzecz Osób z Dysfunkcjami Mózgu.

Raven, J. C. (1991). Test Matryc. Wersja Standard. Seria A, B, C, D, E. Warszawa: Pracownia Testów Psychologicznych Polskiego Towarzystwa Psychologicznego.

Rosenthal, E. N., Riccio, C. A., Gsanger, K. M., \& Jarratt, K. P. (2006). Digit Span components as predictors of attention problems and executive functioning in children. Archives Of Clinical Neuropsychology: The Official Journal Of The National Academy Of Neuropsychologists, 21(2), 131-139. Shessel, I., \& Reiff, H. B. (1999). Experiences of Adults with Learning Disabilities: Positive and Negative Impacts and Outcomes. Learning Disabilities Quarterly, 22(4), 305-316.

Snowling, M. (2000). Dyslexia. Oxford: Blackwell Publishers.

Sochacka, K. (2004). Nabywanie umiejętności czytania - różnice w badaniach dzieci polskich i anglojęzycznych. In M. Bogdanowicz \& M. Smoleń (Eds.), Dysleksja w kontekście nauczania języków obcych (pp. 54-62). Gdańsk: Wydawnictwo HARMONIA.

Sonbul, S., \& Schmitt, N. (2010). Direct teaching of vocabulary after reading: is it worth the effort? ELT Journal: English Language Teachers Journal, 64(3), 253-26o. doi: 10.1093/elt/ccpo59 Sparks, R. L., \& Ganschow, L. (1993). The impact of native language-learning problems on foreignlanguage learning - case-study illustrations of the linguistic coding deficit hypothesis. Modern Language Journal, 77(1), 58-74. doi: 10.2307/329559

Stahl, S. A., \& Fairbanks, M. M. (1986). The effects of vocabulary instruction: A model-based metaanalysis. Review of Educational Research, 56, 72-110.

Swanborn, M. S. L., \& de Glopper, K. (2002). Impact of Reading Purpose on Incidental Word Learning From Context. Language Learning, 52(1), 95.

Swanson, H. L., \& Sáez, L. (2003). Memory difficulties in children and adults with learning 
disabilities. In H. L. Swanson, K. R. Harris, \& S. Graham (Eds.), Handbook of learning disabilities (pp. 182-198). New York-London: Guilford Press.

Szczerbiński, M. (2007). Dysleksja rozwojowa: próba definicji. In M. Kostka-Szymańska \& G.

Krasowicz-Kupis (Eds.), Dysleksja. Problem znany czy nieznany? (pp. 47-72). Lublin: Wydawnictwo UMCS.

Thomson, J. M., Richardson, U., \& Goswami, U. (2005). Phonological similarity neighborhoods and children's short-term memory: Typical development and dyslexia. Memory \& Cognition, 33(7), $1210-1219$.

Tomaszczyk, J. Słowniki ISEL. Retrieved 29 October 14 from http://www.isel.edu.pl/slowniki/ Wang, M., \& Koda, K. (2007). Commonalities and differences in word identification skills among learners of English as a second language. Language Learning, 57(Suppl 1), 201-222.

Wolf, M., \& Bowers, P. G. (1999). The double-deficit hypothesis for the developmental dyslexias. Journal of Educational Psychology, 91(3), 415-438. doi: 10.1037/0022-0663.91.3.415

Wolf, M., \& Bowers, P. G. (2000). Naming-speed processes and developmental reading disabilities: An introduction to the special issue on the double-deficit hypothesis. Journal of Learning Disabilities, 33(4), 322-324. doi: 10.1177/002221940003300404

Wolf, M., Bowers, P. G., \& Biddle, K. (2000). Naming-speed processes, timing, and reading: A conceptual review. Journal of Learning Disabilities, 33(4), 387-407. doi: 10.1177/002221940003300409 Woźnicki, T., \& Zawadzka, E. (1981). Fazy procesu przyswajania języka obcego. Warszawa: Państwowe Wydawnictwo Naukowe.

Electronic source:

www.cke.pl; retrieved 11 September 2014

\section{Biographical note}

Marta Łockiewicz - Assistant Professor in the Division of Psychology and Psychopathology of Development, Institute of Psychology, Social Sciences Department, University of Gdansk. Scientific Interests: specific reading and writing difficulties, school failures prevention, psycholinguistics. Currently studies Polish students with dyslexia difficulties in learning English as a foreign language. Member of Polish Dyslexia Association.

MARTYNA JASKUlSKA - a doctoral student in the Institute of English and American Studies, Faculty of Languages, University of Gdansk. Scientific interests: dyslexia in English as L2, psycholinguistics, sociolinguistics. Works as an English teacher in Derdowski High School in Kartuzy. 